\title{
Fulvimonas soli gen. nov., sp. nov., a $\gamma$-proteobacterium isolated from soil after enrichment on acetylated starch plastic
}

Laboratorium voor Microbiologie, Vakgroep Biochemie, Fysiologie en Microbiologie, Universiteit Gent, K. L. Ledeganckstraat 35, B-9000 Gent, Belgium

\author{
Joris Mergaert, Margo C. Cnockaert and Jean Swings
}

\author{
Author for correspondence: Joris Mergaert. Tel: +329264 5120. Fax: + 3292645092. \\ e-mail: joris.mergaert@rug.ac.be
}

Keywords: Fulvimonas soli, $\gamma$-Proteobacteria, acetylated starch plastic, taxonomy, phylogeny

\section{INTRODUCTION}

In the last few decades, several biodegradable plastics have been developed. These materials offer potential applications in single-use articles that can be disposed of by biological waste treatment. To test the biodegradability of these materials, several approaches have been followed, ranging from in situ tests in the environment, where the materials are expected to end up as waste, to standardized in vitro tests using selected cultures. The latter approach has been applied successfully to the biodegradation testing of bacterial and synthetic polyester-based plastics (Mergaert et al., 2000). In vitro tests yield sufficiently reproducible results for comparative studies and generate suitable partially degraded material for chemical, morphological and physical analysis. One of the prerequisites

Published online ahead of print on 1 March 2002 as DOI 10.1099/ ijs.0.01995-0.

Abbreviation: REP-PCR, repetitive extragenic palindromic DNA PCR.

The GenBank/EMBL/DDBJ accession number for the 165 rDNA sequence of strain LMG $19981^{\top}$ is AJ311653. is that a suitable biodegrading microbial strain is available.

Apart from biodegradable polyesters, chemically modified natural polysaccharides, such as acetylated starch, have been developed as biodegradable plastics (Fritz et al., 1994). Enzymic tests conducted at high temperatures showed that these materials are depolymerized (Coma et al., 1995; Copinet et al., 1997). However, data on microbial degradation in mesophilic conditions are lacking, and test strains are not available.

To obtain isolates of soil bacterial strains that are able to degrade plasticized acetylated starch, we set up enrichment cultures with plastic granules as the sole source of carbon. Although growth of the cultures was poor, we isolated 75 strains and tested their ability to degrade acetylated starch by using the clear-zone test on agar media containing the plastic in suspension (Mergaert \& Swings, 1996). None of the strains produced clear zones, but six strains grew particularly well and, when the plates were flooded with iodine solution to stain the remaining polymer, large un- 
stained zones appeared around the cell mass, indicating at least partial depolymerization of the polymer. The strains could not be identified by their fatty acid compositions, but were all very similar. It is the purpose of this paper to describe the isolation and taxonomic characterization of these strains and to allocate them to a novel species in a new genus, for which the name Fulvimonas soli gen. nov., sp. nov. is proposed.

\section{METHODS}

Enrichment and isolation of strains. Enrichment cultures were set up in a series of $250 \mathrm{ml}$ Erlenmeyer flasks that contained $100 \mathrm{ml}$ minimal medium $\left(0 \cdot 1 \% \mathrm{NH}_{4} \mathrm{Cl}, 0.05 \%\right.$ $\mathrm{MgSO}_{4} \cdot 7 \mathrm{H}_{2} \mathrm{O}$ and $0.005 \%$ ferric ammonium citrate, in $33 \mathrm{mM} \mathrm{KH} \mathrm{PO}_{4} / \mathrm{Na}_{2} \mathrm{HPO}_{4}$ buffer, $\mathrm{pH}$ 6.8). After autoclaving, the medium was supplemented with plastic granules $(3 \mathrm{~g}$ per flask). The plastic material consisted of granules (Sconacell A; Buna Sow Leuna Olefinverbund, Schkopau) made of partially acetylated maize starch (degree of substitution, $2 \cdot 1$ ) and containing about $16 \%$ polyethylene glycol (with a molecular mass of 400) as the plasticizer. The first flask was inoculated with $1 \mathrm{ml}$ of a suspension of $1 \mathrm{~g}$ wet soil in $9 \mathrm{ml}$ sterile physiological saline (0.85\% NaCl; MacFaddin, 1980). The soil used was collected in October 1998 from the university botanical garden in Gent, Belgium, and had a $\mathrm{pH}$ of 7.8. The flask was incubated at $28^{\circ} \mathrm{C}$ on a rotary shaker at 125 r.p.m. and, after 5 days, a second flask was inoculated with $1 \mathrm{ml}$ suspension taken from the first flask. Culture samples were taken periodically for isolation of bacteria that could potentially degrade the plastic. From serial dilutions in sterile physiological saline, five $10-\mu l$ drops were spotted on minimal agar medium plates overlaid with $10 \mathrm{ml}$ plastic suspension in water agar, in duplicate, and incubated at $28{ }^{\circ} \mathrm{C}$. The plastic suspension was prepared as follows: $1 \mathrm{~g}$ plastic granules was dissolved in $8 \mathrm{ml}$ dichloromethane, $250 \mathrm{ml}$ distilled water was added and the whole was mixed using an ULTRA-TURRAX T25 mixer (IKA-Werke). After the addition of $4 \mathrm{~g}$ agar (Oxoid), the medium was autoclaved for $15 \mathrm{~min}$ and then mixed again using an autoclaved mixing rod. During autoclaving, the solvent evaporates and a stable suspension of the plastic in the medium is obtained. After incubation, one plate of each dilution was flooded with iodine solution ( $1 \mathrm{~g} \mathrm{I}_{2}$ and $2 \mathrm{~g} \mathrm{KI}$ in $100 \mathrm{ml}$ distilled water; MacFaddin, 1980), which stains the undegraded polymer blue; spots produced with degrading cultures were surrounded by unstained zones due to the degradation of the starch polymer chains. Cell mass from drops on the corresponding unflooded plates were streaked on trypticase soy broth (BBL) supplemented with $1.5 \%$ Bacto agar (Difco) (TSBA) to obtain isolated colonies. Seventy-five colonies with various morphologies were purified. The pure cultures were tested for their ability to degrade the polymer by streaking them on plastic-containing medium. After 4 weeks incubation at $28^{\circ} \mathrm{C}$, the plates were flooded with iodine solution to stain the remaining polymer. Strains LMG 19981' ${ }^{\mathrm{T}}$, LMG 19982, LMG 19983, LMG 19984, LMG 19985 and LMG 19986 (BCCM/LMG Bacteria Collection, Universiteit Gent, Belgium), all isolated from the second enrichment bottle after 30 days, showed positive results and were investigated further.

Fatty acid analysis. The strains were grown for $48 \mathrm{~h}$ and their fatty acid methyl esters were extracted and separated by GLC using the MIDI system (Microbial ID), as described previously (Mergaert et al., 1993).
Phenotypic tests. Tests in the commercial systems API ZYM, API 20NE and API 50CHE (bioMérieux) were performed using 1-day cultures grown on standard methods agar, containing $\left(1^{-1}\right) 5 \mathrm{~g}$ tryptone (Oxoid), $2.5 \mathrm{~g}$ yeast extract (Oxoid), 1 g glucose and $15 \mathrm{~g}$ agar (Oxoid no. 1) in distilled water, $\mathrm{pH} 7 \cdot 0$. The API ZYM tests were read after $4 \mathrm{~h}$ incubation at $28{ }^{\circ} \mathrm{C}$; all other API tests were read after $48 \mathrm{~h}$. For Biolog metabolic fingerprinting, strains were grown on TSBA. Suspensions were prepared, and Biolog GN microplates inoculated, as recommended by the manufacturer (Biolog). After $24 \mathrm{~h}$ incubation at $28^{\circ} \mathrm{C}$, the absorbances obtained in the wells were read with a microplate reader (Molecular Devices). The resulting absorbances were transformed into positive, borderline (weak reaction) and negative scores by the Biolog MicroStation System software program (release 3.50). Gram reactions and oxidase, catalase and starch hydrolysis were investigated using conventional media and methods (MacFaddin, 1980). Growth on polyethylene glycol (molecular mass 400; Sigma) was tested in a minimal liquid medium containing $0.25 \% \mathrm{MgSO}_{4} .7 \mathrm{H}_{2} \mathrm{O}$, $0 \cdot 25 \% \mathrm{KCl}, 0 \cdot 125 \% \mathrm{NH}_{4} \mathrm{H}_{2} \mathrm{PO}_{4}, \mathrm{pH} 6 \cdot 8$, in distilled water, supplemented with $0.5 \%$ carbon-source substrate (D-glucose was used as a positive control; no carbon source as negative control). Flagella staining was carried out using the method described by Heimbrook et al. (1986). Degradation of lindane was determined as described by Thomas et al. (1996).

16S rDNA sequencing. DNA preparation and $16 \mathrm{~S}$ rDNA sequence analysis were carried out as described previously (Mergaert et al., 2001). The closest related sequences were found using the FASTA program. Phylogenetic analysis was performed using the BIONUMERICS software package (Applied Maths; http://www.applied-maths.com/), taking into account homologous nucleotide positions after discarding all unknown bases and gaps. Using the same software package, a neighbour-joining dendrogram (Saitou \& Nei, 1987) was constructed based on global alignment of the sequence similarities.

DNA preparation, determination of DNA base composition and DNA-DNA hybridizations. DNA was prepared from cells grown on nutrient agar (Oxoid) at $28^{\circ} \mathrm{C}$, according to the method of Pitcher et al. (1989).

DNA base composition was determined using an HPLC method. DNA was enzymically degraded into nucleosides as described by Mesbah et al. (1989). The nucleoside mixture obtained was then separated by HPLC using a Waters Symmetry Shield C8 column thermostatted at $37^{\circ} \mathrm{C}$. The solvent was $0.02 \mathrm{M} \mathrm{NH}_{4} \mathrm{H}_{2} \mathrm{PO}_{4}$, pH $4 \cdot 0$, with $1.5 \%$ acetonitrile. Unmethylated lambda phage DNA (Sigma) was used as the calibration reference.

DNA-DNA hybridizations were carried out with photobiotin-labelled probes in microplate wells as described by Ezaki et al. (1989), using an HTS7000 Bio Assay Reader (Perkin Elmer) for the fluorescence measurements. The hybridization temperature was $50{ }^{\circ} \mathrm{C}$. Reciprocal experiments were performed for every pair of strains.

Repetitive extragenic palindromic DNA PCR (REP-PCR) genomic fingerprinting. REP-PCR (based on primers targeting the repetitive extragenic palindromic sequence) genomic fingerprints were obtained using the primers REP1R-I and REP2-I (Versalovic et al., 1991), as described by Rademaker \& de Bruijn (1997) and Rademaker et al. (2000). Numerical analysis was carried using the BIONUMERICS software package, as described by the same authors. 


\section{RESULTS AND DISCUSSION}

The six strains consisted of small, short, motile rods, staining Gram-negative and forming mucoid, deepyellow colonies on TSBA after 5 days incubation.

\section{Table 1. Fatty acid composition of Fulvimonas soli}

Contents are percentages of total fatty acids given as ranges for six strains. The following constituted $<1 \%$ of the total: $10: 0$ iso, $12: 0$ iso, $13: 0$ iso, $12: 03 \mathrm{OH}$, unknown $13 \cdot 564,14$ : 0 iso, 14:0, 13:0 2OH, 15:1 iso $\mathrm{F}, 16: 1$ iso $\mathrm{H}, 17: 0$ cyclo, 16: 0 iso $3 \mathrm{OH}, 18: 0$ iso, 18:0, 17:0 iso $3 \mathrm{OH}, 19: 0$ iso, 20:0, summed feature 1 . Unknown fatty acids are designated by their equivalent chain lengths, relative to the chain lengths of known straight-chain saturated fatty acids. Summed feature 1 comprises any combination of 13:0 $3 \mathrm{OH}, 15: 1$ iso $\mathrm{H}$ and 15: 1 iso I (capitals refer to unknown positions of double bonds). Summed feature 3 comprises either 15:0 iso $2 \mathrm{OH}$ or $16: 1 \omega 7 c$ or both.

\begin{tabular}{|lc|}
\hline Fatty acid & Range \\
\hline $11: 0$ iso & $4 \cdot 0-5 \cdot 6$ \\
Unknown $11 \cdot 798$ & $2 \cdot 6-3 \cdot 5$ \\
$11: 0$ iso $3 \mathrm{OH}$ & $5 \cdot 6-7 \cdot 4$ \\
$12: 0$ iso $3 \mathrm{OH}$ & $0 \cdot 6-1 \cdot 4$ \\
$13: 0$ iso $3 \mathrm{OH}$ & $3 \cdot 8-4 \cdot 3$ \\
$15: 0$ iso & $25 \cdot 8-31 \cdot 2$ \\
$15: 0$ anteiso & $2 \cdot 8-4 \cdot 0$ \\
$16: 0$ iso & $3 \cdot 7-13 \cdot 2$ \\
$16: 0$ & $0 \cdot 4-2 \cdot 2$ \\
$17: 1$ iso $\omega 9 c$ & $15 \cdot 8-21 \cdot 7$ \\
$17: 0$ iso & $10 \cdot 9-15 \cdot 0$ \\
$17: 0$ anteiso & $0 \cdot 6-1 \cdot 1$ \\
$17: 1 \omega 6 c$ & $0 \cdot 3-1 \cdot 5$ \\
Summed feature 3 & $2 \cdot 0-2 \cdot 8$ \\
\hline
\end{tabular}

After incubation on plastic-containing medium and flooding of the plates with iodine solution, large unstained zones appeared around the cell mass, indicating partial depolymerization of the acetylated starch. The strains displayed very similar fatty acid compositions (Table 1) that consisted mainly of branched fatty acids ( $>90 \%$ of total). Comparison of the profiles with those contained in the database yielded no matches.

The biochemical and physiological characteristics of the strains are given in Table 2. In addition, use of the Biolog system revealed that all six strains showed respiration reactions in the presence of Tween 40, Tween 80, D-galactose and D-glucose. Respiration was positive or weak for dextrin, $N$-acetyl $\beta$-D-glucosamine, $\mathrm{D}$-fucose, maltose, D-trehalose, $\beta$-hydroxybutyric acid, alaninamide, L-alanine and L-alanyl glycine. For 73 carbon sources, no respiration or weak respiration was observed and, for 15 carbon sources, the reactions differed between strains (negative, weak positive or positive).

To investigate the phylogenetic position of the strains, the $16 \mathrm{~S}$ rDNA sequence of strain LMG $19981^{\mathrm{T}}$ was determined and subjected to comparative analysis. Sequence database searches revealed that the sequence was similar to those of Rhodanobacter lindaniclasticus RP5557 ${ }^{\mathrm{T}}$ (96.7\% sequence similarity) and Frateuria aurantia $\mathrm{LMG} 1558^{\mathrm{T}}(96 \cdot 0 \%)$. Other members of the $\gamma$-subclass of the Proteobacteria, including members of Xanthomonas, Stenotrophomonas and Xylella, showed less than $92 \%$ sequence similarity. A neighbourjoining dendrogram is shown in Fig. 1.

To investigate the genomic diversity of the isolates, REP-PCR fingerprinting was applied. Numerical analysis divided the profiles in two groups, indicating that the strains were derived from at least two different

Table 2. Biochemical and physiological characteristics of Fulvimonas soli

+, Positive reaction; -, negative reaction; \pm , weak positive reaction. All Fulvimonas soli strains were positive for the following phenotypic tests: growth on D-glucose and maltose, $p$-nitrophenyl$\beta$-D-galactosidase, hydrolysis of starch and aesculin, oxidase, catalase, alkaline phosphatase, acid phosphatase, $\mathrm{C}_{8}$ esterase lipase, $\beta$-D-glucosidase, $N$-acetyl- $\beta$-D-glucosaminidase, leucine arylamidase, valine arylamidase, phosphoamidase, growth at $37^{\circ} \mathrm{C}$. They were all negative for the following features: nitrate reduction, indole production, arginine dihydrolase, urease, gelatin liquefaction, growth on L-arabinose, D-mannitol, D-gluconate, caprate, adipate, citrate and phenylacetate, $\mathrm{C}_{14}$ lipase, cystine arylamidase, trypsin, chymotrypsin, $\alpha$-D-galactosidase, $\beta$-D-glucuronidase, $\alpha$-D-mannosidase and $\alpha$-D-fucosidase, acid production from any of the carbohydrates included in the API 50CHE strip, degradation of lindane, growth on polyethylene glycol 400 and growth at $4{ }^{\circ} \mathrm{C}$.

\begin{tabular}{|lcccccc|}
\hline Characteristic & LMG & LMG & LMG & LMG & LMG & LMG \\
& $\mathbf{1 9 9 8 1}^{\text {T }}$ & $\mathbf{1 9 9 8 2}$ & $\mathbf{1 9 9 8 3}$ & $\mathbf{1 9 9 8 4}$ & $\mathbf{1 9 9 8 5}$ & $\mathbf{1 9 9 8 6}$ \\
\hline Growth on: & & & & & & \\
$\quad$ D-Mannose & - & \pm & \pm & - & - & \pm \\
$\quad N$-Acetyl $\beta$-D-glucosamine & - & \pm & + & - & - & - \\
$\quad$ Malate & - & \pm & + & \pm & - & \pm \\
Cystine arylamidase & - & - & - & - & - & + \\
$\alpha$-D-Glucosidase & - & - & + & + & + & + \\
\hline
\end{tabular}




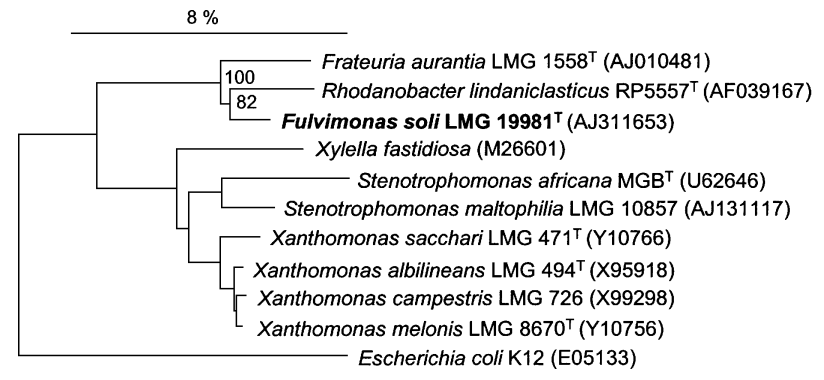

Fig. 1. Neighbour-joining dendrogram showing the estimated phylogenetic relationships of Fulvimonas soli and the nearest members of the $\gamma$-Proteobacteria. Escherichia coli was included as an outgroup. Bootstrap values of branches involved are shown as percentages of 1000 replicates. Bar, $8 \%$ sequence divergence.

clones. The first REP-PCR group contained strains LMG 19981'T, LMG 19984, LMG 19985 and LMG 19986, and the second group contained strains LMG 19982 and LMG 19983. The representative strains LMG $19981^{\mathrm{T}}$ and LMG 19982 showed 93\% DNADNA binding to each other and less than $10 \%$ DNA-DNA reassociation to Frateuria aurantia $\mathrm{LMG}$ $1558^{\mathrm{T}}$. Unfortunately, the monotype strain RP $5557^{\mathrm{T}}$ of the species Rhodanobacter lindaniclasticus is no longer extant, either with the authors of the recent description of the species (Nalin et al., 1999) or with the LMG Bacteria Collection, in which the strain was deposited as LMG $18385^{\mathrm{T}}$. The $\mathrm{G}+\mathrm{C}$ contents of DNA from strains LMG $19981^{\mathrm{T}}$ and LMG 19982 were 71.9 and $71.5 \mathrm{~mol} \%$, respectively, which are 7-9 mol \% higher than those of Frateuria aurantia LMG $1558^{\mathrm{T}}(63.5 \mathrm{~mol} \%)$ and Rhodanobacter lindaniclasticus RP5557 $7^{\mathrm{T}}$ (63 mol\%, reported by Nalin et al., 1999).

All data support the creation of a new genus, for which the name Fulvimonas is proposed, containing the single species Fulvimonas soli sp. nov. The species can be differentiated from Frateuria aurantia and Rhodanobacter lindaniclasticus by means of several phenotypic features (Table 3). Unlike Frateuria aurantia, Fulvimonas soli is oxidase-positive and does not ferment sugars. The species can be differentiated from Rhodanobacter lindaniclasticus by its motility, its ability to grow on maltose but not caprate or citrate, its ability to form $\beta$-D-galactosidase and its ability to degrade starch but not lindane.

\section{Description of Fulvimonas gen. nov.}

Fulvimonas (Ful.vi.mo'nas. L. adj. fulvus deep-yellow; Gr. monas a unit, monad; N.L. fem. n. Fulvimonas deep-yellow monad).

Table 3. Differential tests between Fulvimonas soli, Frateuria aurantia LMG $1558^{\top}$ and Rhodanobacter lindaniclasticus RP5557 ${ }^{\top}$

+ , Positive; - , negative; ND, not determined. Fulvimonas soli $\mathrm{LMG} 19981^{\mathrm{T}}$ shows the same reactions as the species.

\begin{tabular}{|c|c|c|c|}
\hline Feature & $\begin{array}{l}\text { Fulvimonas soli } \\
\text { (6 strains) }\end{array}$ & $\begin{array}{c}\text { Frateuria aurantia } \\
\text { LMG } \text { 1558 }^{\mathrm{T}}\end{array}$ & $\begin{array}{l}\text { R. lindaniclasticus } \\
\text { RP5557 }^{\mathrm{T}} *\end{array}$ \\
\hline Motility & + & + & - \\
\hline \multicolumn{4}{|l|}{ Acid from: } \\
\hline D-Glucose & - & + & - \\
\hline D-Ribose & - & + & ND \\
\hline D-Xylose & - & + & ND \\
\hline D-Galactose & - & + & ND \\
\hline D-Mannose & - & + & ND \\
\hline L-Arabinose & - & + & ND \\
\hline \multicolumn{4}{|l|}{ Growth on: } \\
\hline Maltose & + & + & - \\
\hline Caprate & - & - & + \\
\hline Citrate & - & - & + \\
\hline$p$-Nitrophenyl- $\beta$-D-galactosidase & + & - & - \\
\hline$\beta$-D-Glucosidase & + & - & ND \\
\hline$N$-Acetyl- $\beta$-D-glucosaminidase & + & - & ND \\
\hline Oxidase & + & - & + \\
\hline Aesculin hydrolysis & + & - & + \\
\hline Starch degradation & + & ND & - \\
\hline Lindane degradation & - & $\mathrm{ND}$ & + \\
\hline Mean DNA G $+\mathrm{C}$ content $(\mathrm{mol} \%)$ & $71 \cdot 7 \dagger$ & $63 \cdot 5$ & 63 \\
\hline
\end{tabular}

* Data from Nalin et al. (1999).

$\uparrow$ Mean for strains LMG $19981^{\mathrm{T}}$ and LMG 19982. 
Gram-negative, single rods each about $0.5 \times 2 \mu \mathrm{m}$ and motile by a single polar flagellum, without spores or capsules. Aerobic, chemo-organotrophic. Grows on acetylated starch, starch, maltose and D-glucose, but assimilates few other substrates. Does not ferment sugars. Oxidase- and catalase-positive. Mesophilic. The cells contain almost exclusively branched fatty acids, with 15:0 iso, 17:1 $\omega 9 c$ iso and 17:0 iso as the main constituents. Fulvimonas belongs to the $\gamma$-subclass of the Proteobacteria. The type species is Fulvimonas soli.

\section{Description of Fulvimonas soli sp. nov.}

Fulvimonas soli (so'li. L. neut. gen. n. soli of soil, the source of the organism).

Deep-yellow, mucoid, low convex, translucent colonies, $2-3 \mathrm{~mm}$ in diameter and with entire margins, are formed on TSBA plates after 5 days at $28^{\circ} \mathrm{C}$. Cellular, biochemical and physiological features are as described for the genus. In addition, no growth occurs on L-arabinose, D-mannitol, D-gluconate, caprate, citrate or phenylacetate. Degrades aesculin but does not liquefy gelatin or reduce nitrate. Produces alkaline and acid phosphatase and $\beta$-D-galactosidase but not arginine dihydrolase or urease. Does not produce indole. Growth occurs at $28-37^{\circ} \mathrm{C}$ but not at $4{ }^{\circ} \mathrm{C}$. Additional features are given in Table 2. Strains were isolated from a soil sample, after enrichment on acetylated starch plastic. The $\mathrm{G}+\mathrm{C}$ contents of two strains are 71.5 and $71.9 \mathrm{~mol} \%$. The type strain is LMG $19981^{\mathrm{T}}\left(=\right.$ DSM $\left.14263^{\mathrm{T}}\right)$.

\section{ACKNOWLEDGEMENTS}

This work has been carried out within the scope of FAIR project CT98-3919 ' New functional biopolymer-natural fibre composites from agricultural resources' financed by the European Commission.

\section{REFERENCES}

Coma, V., Copinet, A., Couturier, Y. \& Prudhomme, J. C. (1995). Biofragmentation of acetylated starch by the $\alpha$-amylase of Aspergillus oryzae. Starch 47, 100-107.

Copinet, A., Coma, V., Legin, E., Couturier, Y. \& Prudhomme, J. C. (1997). Hydrolysis of acetylated starches with a thermostable $\alpha$ amylase. Starch 49, 492-498.
Ezaki, T., Hashimoto, Y. \& Yabuuchi, E. (1989). Fluorometric deoxyribonucleic acid-deoxyribonucleic acid hybridization in microdilution wells as an alternative to membrane filter hybridization in which radioisotopes are used to determine genetic relatedness among bacterial strains. Int J Syst Bacteriol 39, 224-229.

Fritz, H.-G., Seidenstücker, T., Bölz, U., Juza, M., Schroeter, J. \& Endres, H.-J. (1994). Study on production of thermoplastics and fibres based mainly on biological materials. Publication no. EUR 16102 EN. Stuttgart: European Commission Directorate-General XII for Science Research and Development.

Heimbrook, M. E., Wang, W. L. L. \& Campbell, G. (1986). Easily made flagella stains. American Society for Microbiology National Meeting, 1986, Washington, DC. Abstract R22.

MacFaddin, J. F. (1980). Biochemical Tests for the Identification of Medical Bacteria, 2nd edn. Baltimore: Williams \& Wilkins.

Mergaert, J. \& Swings, J. (1996). Biodiversity of microorganisms that degrade bacterial and synthetic polyesters. J Ind Microbiol 17, 463-469.

Mergaert, J., Verdonck, L. \& Kersters, K. (1993). Transfer of Erwinia ananas (synonym, Erwinia uredovora) and Erwinia stewartii to the genus Pantoea emend. as Pantoea ananas (Serrano 1928) comb. nov. and Pantoea stewartii (Smith 1898) comb. nov., respectively, and description of Pantoea stewartii subsp. indologenes subsp. nov. Int J Syst Bacteriol 43, $162-173$.

Mergaert, J., Ruffieux, K., Bourban, C., Storms, V., Wagemans, W., Wintermantel, E. \& Swings, J. (2000). In vitro biodegradation of polyester-based plastic materials by selected bacterial cultures. J Polym Environ 8, 17-27.

Mergaert, J., Verhelst, A., Cnockaert, M. C., Tan, T.-L. \& Swings, J. (2001). Characterization of facultative oligotrophic bacteria from polar seas by analysis of their fatty acids and $16 \mathrm{~S}$ rDNA sequences. Syst Appl Microbiol 24, 98-107.

Mesbah, M., Premachandran, U. \& Whitman, W. B. (1989). Precise measurement of the $\mathrm{G}+\mathrm{C}$ content of deoxyribonucleic acid by highperformance liquid chromatography. Int J Syst Bacteriol 39, 159-167.

Nalin, R., Simonet, P., Vogel, T. M. \& Normand, P. (1999). Rhodanobacter lindaniclasticus gen. nov., sp. nov., a lindane-degrading bacterium. Int J Syst Bacteriol 49, 19-23.

Pitcher, D. G., Saunders, N. A. \& Owen, R. J. (1989). Rapid extraction of bacterial genomic DNA with guanidinium thiocyanate. Lett Appl Microbiol 8, 151-156.

Rademaker, J. L. W. \& de Bruijn, F. J. (1997). Characterization and classification of microbes by rep-PCR genomic fingerprinting and computer assisted pattern analysis. In DNA Markers: Protocols, Applications and Overviews, pp. 151-171. Edited by G. Caetano-Anollés \& P. M. Gresshoff. New York: Wiley.

Rademaker, J. L. W., Hoste, B., Louws, F. J., Kersters, K., Swings, J., Vauterin, L., Vauterin, P. \& de Bruijn, F. J. (2000). Comparison of AFLP and rep-PCR genomic fingerprinting with DNA-DNA homology studies: Xanthomonas as a model system. Int J Syst Evol Microbiol 50, 665-677.

Saitou, N. \& Nei, M. (1987). The neighbor-joining method: a new method for reconstructing phylogenetic trees. Mol Biol Evol 4, 406-425.

Thomas, J.-C., Berger, F., Jacquier, M., Bernillon, D., Baud-Grasset, F., Truffaut, N., Normand, P., Vogel, T. M. \& Simonet, P. (1996). Isolation and characterization of a novel $\gamma$-hexachlorocyclohexanedegrading bacterium. J Bacteriol 178, 6049-6055.

Versalovic, J., Koeuth, T. \& Lupski, J. R. (1991). Distribution of repetitive DNA sequences in eubacteria and application to fingerprinting of bacterial genomes. Nucleic Acids Res 19, 6823-6831. 